\title{
Food deprivation affects vertical distribution and activity of a marine fish in a thermal gradient: potential energy-conserving mechanisms
}

\author{
Susan M. Sogard*, Bori L. Olla \\ Alaska Fisheries Science Center, National Marine Fisheries Service, Hatfield Marine Science Center, Newport, \\ Oregon 97365, USA
}

\begin{abstract}
The effects of reduced food availability on the behavior of juvenile walleye pollock Theragra chalcogramma were examined in laboratory experiments designed to test for potential energyconserving responses. Groups of juvenile fish were held on 1 of 6 ration treatments ranging from ad libitum to near starvation, and then vertical distribution and activity levels were quantified in a $2.5 \mathrm{~m}$ deep water column under isothermal and thermally stratified conditions. Stratification resulted in a general shift to the upper, warmer layer in the 2 experiments employing a sharp thermocline at middepth, but the occurrence of fish in the colder bottom layer varied with different ration treatments. Movement into cold water increased in intermediate ration groups compared to high ration groups. Since reduced temperatures should reduce metabolic costs, this behavior is consistent with our hypothesis that food deprivation should invoke energy-saving behaviors. However, activity levels increased for fish held on intermediate rations, suggesting that the greater movement into cold water was a corollary result of increased searching for food. Fish in the lowest ration treatments had decreased activity levels, but also decreased their movement into cold water when a sharp thermocline was present, negating potential bioenergetic benefits. In the third experiment, there was a gradual thermal gradient from surface to bottom rather than a sharp thermocline. Temperatures associated with vertical positions of the fish were determined. In this experiment, clear energy-conserving responses to temperature were displayed by food-deprived fish; the average temperatures occupied by fish on starvation rations were 3 to $4^{\circ} \mathrm{C}$ colder than those of the higher ration groups. Based on the high $Q_{10}$ for metabolic rates of juvenile pollock, these reduced temperatures potentially conferred energy savings of up to $34 \%$, relative to the metabolic expenditures of fish on high rations. The contrast in behavior for the lowest ration groups between sharply stratified and gradually stratified conditions suggested that the severity of the temperature gradient influenced the fishes' ability to take advantage of cold water as an energetic refuge. The behavior of fish in the laboratory was consistent with prior observations in the Bering Sea, where juvenile walleye pollock remained in surface waters if food availability was high, but initiated vertical migration into deeper, colder water with reduced prey densities. Results of this study demonstrated a broad flexibility in the behavioral mechanisms used by walleye pollock to deal with declining food levels. The initial response to food limitation was increased activity, indicative of greater searching behavior With extended food deprivation, a switch to energy-conserving behavior was evident. The temperature responses of fish experiencing severe food limitation provided support for a bioenergetic hypothesis of diel vertical migration.
\end{abstract}

KEY WORDS: Behavior Temperature - Starvatıon Bioenergetics - Walleye pollock

\section{INTRODUCTION}

Animals can respond to declining levels of prey abundance by behavioral adaptations that offset or delay the effects of reduced food intake. Two poten-

•E-mail: sogards@ccmail.orst.edu tially incompatible mechanisms can be implemented to reduce the probability of starvation. Foraging behavior can be modified to improve the chances of finding prey. This approach may involve moving to a new location, increasing the amount of time spent searching for prey, increasing the intensity of searching behavior, or changing the type of prey consumed. Alternatively, 
animals can lower energetic costs, thereby extending the amount of time available before energy reserves are depleted. Many behaviors associated with the first strategy, such as increased searching activity, will likely increase energy expenditures. In turn, behaviors that lower metabolic costs, such as quiescence or reduced activity, may decrease the probability of encountering prey patches. Thus, there are trade-offs between the 2 mechanisms in their relative costs and benefits. Wieser (1991) predicted shifts in the 2 types of behavior depending on the extent of food deprivation; locomotor activity and searching behavior should initially increase, despite the energetic costs, to improve the chances of finding food, but if low food conditions continue, metabolic expenditures should be reduced as much as possible to forestall starvation.

Extensive experimental work has demonstrated that fishes do change their foraging behavior as food levels decline, often with an associated ecological cost, such as increased predation risk (see reviews by Lima \& Dill 1990, Milinski 1993). Hungry fish improve their food intake by foraging in habitats with higher predation risk (Magnhagen 1988, Sogard 1994) or by increasing the time spent foraging while reducing vigilance toward predators (Milinski 1984, Godin \& Smith 1988, Morgan 1988, Gotceitas \& Godin 1991).

Evidence of behavioral responses that reduce energetic costs is more limited. One potential mechanism is lower locomotor activity. In juvenile cod, swimming speeds initially increased as food levels declined, then decreased with further food deprivation (Björnsson 1993); $\mathrm{O}_{2}$ consumption rates were 4 to 5 times higher for cod on intermediate rations compared to higher or lower rations. Because the energetic costs of metabolism are directly related to ambient temperature in ectotherms (Cossins \& Bowler 1987), energy conservation can also be achieved by behaviors that lower body temperature. Animals exhibiting lower temperature preferences under reduced food conditions include snakes (Regal 1966), turtles (Gatten 1974), reduviid bugs (Lazzari 1991) and fire ants (Porter \& Tschinkel 1993).

The optimum temperature for growth in fishes generally declines as food availability declines (Brett 1971. Crowder \& Magnuson 1983, Brandt 1993). Under conditions of negative growth, i.e. starvation, occupancy of cold water inhibits loss of condition and increases longevity. Thus, fish should alter their distribution from warmer to colder temperatures when the cost:benefit ratio associated with increased food searching becomes physiologically prohibitive. Modelling studies by Crowder \& Magnuson (1983) and Brandt (1993) suggested that in natural aquatic systems, fish should select habitats that provide optimal bioenergetic benefits, based on the integration of food and temperature distributions. Field data supporting a correlation between food abundance and temperature distribution is evident in cisco Coregonus artedii, which reside in lower temperatures in oligotrophic lakes (presumably food-poor) than in eutrophic lakes (Rudstam \& Magnuson 1985).

Only a few studies have directly tested the influence of food level on behavioral responses in thermal gradients, and conflicting results have been reported. Selection of lower water temperatures at lower food levels, presumably resulting in energy conservation, has been described for juvenile lake charr Salvelinus namaycush (Mac 1985), bluegill Lepomis macrochirus (Stuntz \& Magnuson 1976), American plaice Hippoglossoides platessoides (Morgan 1993), brook trout Salvelinus fontinalis, and rainbow trout Salmo gairdneri (Javaid \& Anderson 1967). Mac's (1985) study examined a full series of ration levels in a broad thermal gradient, with a regular decline in selected temperature as ration decreased. However, Atlantic salmon Salmo salar displayed a significant increase in selected temperature under low rations (Javaid \& Anderson 1967), and in contrast to Stuntz \& Magnuson's (1976) results, Wildhaber \& Crowder (1990) concluded that ration had no influence on temperatures selected by bluegills. Wildhaber \& Crowder (1990) suggested that thermal preferences of bluegill prevailed over energetic considerations, since temperatures selected by fish on low rations declined by $<1^{\circ} \mathrm{C}$ (a $5^{\circ} \mathrm{C}$ decrease was possible in the experimental setup). Mac (1985) also suggested that temperatures selected by fish on low rations did not decrease energetic costs to the fullest extent possible with the temperatures available. Thus, additional trade-offs between the energetic benefits of lower water temperature and the associated physiological and ecological costs presumably modified behavioral choices.

Intermittent use of cold water as an energy-conserving mechanism has been proposed to be a causal factor in vertical migration behavior (McLaren 1963, Brett 1971). Bevelhimer \& Adams (1993) developed a bioenergetics model to determine the migration scenarios that would best enhance growth of kokanee Oncorhynchus nerka under different patterns of prey distribution and abundance. Their simulations reveal clear advantages to migrating into colder water; estimated growth rates were always higher with vertical migration than under any isothermal regime. However, experimental evidence supporting a bioenergetic hypothesis for vertical migration is limited.

In the present study, we examined potential energyconserving behaviors of juvenile walleye pollock Theragra chalcogramma. In the Bering Sea, juveniles displayed a variable pattern of diel vertical migration (Bailey 1989). At night, the fish were concentrated in 
the surface layer above the thermocline. Daytime migration down through the thermocline appeared to be influenced by body size, with smaller fish more likely to remain in surface waters, and by food availability. At a site that had high food levels and high juvenile growth rates, vertical migration did not occur, and juvenile pollock remained in surface waters both day and night. In contrast, at sites with lower food availability and lower growth rates, extensive movement into cold water occurred during the day. These results were consistent with a bioenergetic hypothesis of vertical migration. Bailey (1989) suggested that movement into cold water beneath the thermocline was an energy-saving mechanism employed only by fish experiencing low food conditions. However, it was also possible that vertical migration observed under these conditions was a result of increased searching behavior. In laboratory studies, the introduction of food beneath a thermocline induced transient movements of juvenile walleye pollock (Olla \& Davis 1990) and bluefish (Olla et al. 1985) into cold water to feed. Although these studies documented the effect of the immediate presence of food on tempering avoidance of cold water, they did not examine the influence of varying levels of hunger on food searching behavior.

In a series of laboratory experiments, we held juvenile walleye pollock under varying levels of food deprivation and observed their vertical distribution and activity under isothermal and stratified temperature regimes. By conducting experiments with fish maintained on an extended series of rations from ad libitum to near starvation, we encompassed the full range of potential food levels. Our primary aims were to determine if juvenile walleye pollock modify behavior according to recent foraging success and if movement into cold water is used as a potential means of reducing metabolic costs.

\section{METHODS}

Basic experimental design. Juvenile walleye pollock used in laboratory experiments were collected from May to July in seagrass habitats of Puget Sound, Washington, USA, using 3 collecting methods of otter trawls, beach seines, and a night light/lift trap. The fish were maintained in $450 \mathrm{l}$ holding tanks in a continuously exchanging seawater system at ambient temperatures $\left(\bar{X}=12^{\circ} \mathrm{C}\right)$. The diet consisted of 1 or $2 \mathrm{~mm}$ diameter BioDiet pellets (composition: $45 \%$ protein, $15 \%$ fat, $8.5 \%$ carbohydrate, $31.5 \%$ other) for the first 1 or $2 \mathrm{mo}$ in the lab, then the fish were switched to a prepared diet $(28 \%$ herring, $14 \%$ krill, $14 \%$ squid, and $43 \%$ BioDiet pellets). They were fed ad libitum rations prior to all experiments.
Table 1 Outline of protocol used for experiments testing the influence of ration level on the behavior of juvenile walleye pollock in vertical thermal gradients

\begin{tabular}{|c|c|c|}
\hline \multirow[t]{2}{*}{ Ration level } & \multicolumn{2}{|c|}{ Thermal gradient type } \\
\hline & Sharp & Gradual \\
\hline $10 \% B W d^{-1}$ for $10 d$ & Expts 1,2 & Expt 3 \\
\hline $2.5 \% \mathrm{BW} \mathrm{d}^{-1}$ for $10 \mathrm{~d}$ & Expt 1 & Expt 3 \\
\hline $0.5 \% \mathrm{BW} \mathrm{d}-1$ for $10 \mathrm{~d}$ & Expts 1,2 & Expt 3 \\
\hline $0.5 \% \mathrm{BW} \mathrm{d}^{-1}$ for $30 \mathrm{~d}$ & Expt 1 & Expt 3 \\
\hline $0 \% \mathrm{BW} \mathrm{d}^{-1}$ for $30 \mathrm{~d}$ & Expt 2 & Expt 3 \\
\hline $0 \% \mathrm{BW} \mathrm{d}^{-1}$ for $54 \mathrm{~d}$ & Expt 2 & Expt 3 \\
\hline
\end{tabular}

The influence of varying rations on the behavior of juvenile pollock was tested in a series of 3 experiments. Fish were randomly assigned to 1 of 6 rations, with 5 fish per group and 3 or 4 groups for each ration level. Ration treatments included the following: 10, 2.5, and $0.5 \%$ body weight $(\mathrm{BW}) \mathrm{d}^{-1}$ for $10 \mathrm{~d}, 0.5 \% \mathrm{BW} \mathrm{d}^{-1}$ for $30 \mathrm{~d}$, no food for $30 \mathrm{~d}$, and no food for $54 \mathrm{~d}$ (Table 1). Fish were maintained on the assigned ration in 4401 tanks for the prescribed period of time prior to observation in the experimental tanks. Food (for positive ration groups) was scattered across the water surface once each day, with the time of feeding varied across days. Total lengths and wet weights were measured at the beginning and end of this period to measure growth. An index of body condition was calculated as (wet weight, $\mathrm{g}) \times(\text { total length, } \mathrm{mm})^{-3} \times 10^{6}$. For all 3 experiments, condition indices did not differ among treatments prior to the ration period (ANOVA, all $\mathrm{p}>$ $0.10)$.

Behavioral observations for each experiment were conducted in two $15000 \mathrm{l}$ controlled temperature tanks $(2.5 \times 2.5 \times 2.5 \mathrm{~m})$ with plexiglas front walls. To facilitate behavioral observations, a panel in the middle of each tank restricted fish to the front half. Overhead light was provided by a $400 \mathrm{~W}$ lamp channeled into a tube over the tank. Photoperiod in all experiments was $12 \mathrm{~h} \mathrm{L:12} \mathrm{h} \mathrm{D}$. Dusk and dawn transitions were achieved over a $3 \mathrm{~h}$ period with a traveling shutter that moved in front of the light source. Stratified conditions were created by adding cold water to the bottom of the tank, with surface water removed by an overflow pipe. Water temperatures were monitored by a vertical array of 15 thermistors implanted along one wall of each tank. During the observation period in the experimental tanks, fish continued to receive their assigned ration, with a similar feeding schedule. No behavioral data were collected for at least 30 min following feeding.

Expts 1 and 2-sharp thermal gradient. All groups were videotaped with $8 \mathrm{~mm}$ cameras. Four sets of 10 min observations ( 3 sets in Expt 2) were recorded 
during daytime hours on each day of an experiment. Spatial positions of the fish were tabulated by dividing the tank into 16 blocks ( 4 vertical columns and 4 horizontal rows) and noting the location of each fish every minute over a 10 min period. Indices of general motor activity were calculated by following the movements of a single fish and counting the number of times it moved from one block to another over a $5 \mathrm{~min}$ period. Activity ambit, the area of movement by an individual moving through the tank, was derived as the total number of different blocks that a fish entered during the 5 min activity observation. Ambit values could range from 1 (the fish remained in the same block for $5 \mathrm{~min}$ ) to 16 (the fish visited each block in the tank at least once during $5 \mathrm{~min}$ ). Activity levels and activity ambits of 2 individuals were measured in conjunction with each $10 \mathrm{~min}$ set of fish location data. Activity scores and spatial positions were measured during both isothermal and stratified conditions.

For Expts 1 and 2, pollock behavior was monitored for $4 \mathrm{~d}$. A group was added to the tank on the morning of Day 1 and allowed 3 or $4 \mathrm{~h}$ of acclimation prior to observations. The first 2 days were isothermal. On the morning of the 3rd day, a thermocline was set up in the tank, and fish were observed for an additional $2 \mathrm{~d}$ under stratified conditions. Water temperatures during isothermal conditions were maintained between 8.5 and $9.5^{\circ} \mathrm{C}$. In stratified treatments, average water temperatures were $8.5^{\circ} \mathrm{C}$ in the upper layer and $2.0^{\circ} \mathrm{C}$ in the lower layer. The thermocline was positioned at slightly below the mid-point of the tank, with the full thermal transition extending across approximately $30 \mathrm{~cm}$.

When the water column in the tank was stratified, we measured the duration in seconds of each excursion (dive) by a fish into the cold water beneath the thermocline during a 10 min period. The percentage of time spent in cold water was calculated by summing these dive durations and dividing by $3000 \mathrm{~s}$ (the maximum amount possible for 5 fish combined during $10 \mathrm{~min})$. Because individuals could not be recognized, it was not possible to determine the dive history for each fish separately.

Expt 1 used fish from the 1991 year class, with a total length ranging from 112 to $158 \mathrm{~mm}(\bar{x}=137)$. Four ration treatments were compared: $10 \% \mathrm{BW} \mathrm{d}^{-1}$ for $10 \mathrm{~d}_{i} 2.5 \% \mathrm{BW} \mathrm{d}^{-1}$ for $10 \mathrm{~d}_{\mathrm{i}} 0.5 \% \mathrm{BW} \mathrm{d}^{-2}$ for $10 \mathrm{~d}_{\mathrm{i}}$ and $0.5 \% \mathrm{BW} \mathrm{d}^{-1}$ for $30 \mathrm{~d}$ (Table 1 ). In Expt 2, the low ration treatments were extended to near starvation level. Our goal was to test fish under the most extreme state of food deprivation prior to starvation, a state that had not been achieved in Expt 1. Thus, Expt 2 repeated 2 of the rations used in Expt $1\left(10 \% \mathrm{BW} \mathrm{d}^{-1}\right.$ for $10 \mathrm{~d}$ and $0.5 \%$ $\mathrm{BW} \mathrm{d}^{-1}$ for $10 \mathrm{~d}$ ) and additionally examined starvation rations of $0 \% \mathrm{BW} \mathrm{d}^{-1}$ for $30 \mathrm{~d}$ and $54 \mathrm{~d}$ (Table 1). Expt 2 used fish from the 1992 year class, with total length ranging from 108 to $167 \mathrm{~mm}(\bar{x}=126)$.

Expt 3 -gradual thermal gradient. In stratified treatments of the first 2 experiments, the temperature transition was a sharp thermocline, and in measuring diving behavior we classified fish as being either above or below the thermocline. Some fish, particularly in the starvation ration groups of Expt 2, appeared to spend much of their time within the narrow thermal transition zone. We hypothesized that a preference for lower temperatures, but not as low as the $2^{\circ} \mathrm{C}$ present in the bottom layer, could be responsible for this behavior. Thus, the goal of Expt 3 was to provide juvenile pollock with a more gradual thermal transition and determine the actual temperature occupied by each fish during an observation.

To achieve a gradual thermal gradient, we chilled and added water to the experimental tanks in $2^{\circ} \mathrm{C}$ intervals, resulting in a relatively smooth transition from about $9.5^{\circ} \mathrm{C}$ at the surface to about $2^{\circ} \mathrm{C}$ at the bottom. Each group was observed for $2 \mathrm{~d}$ in an isothermal water column, followed by $3 \mathrm{~d}$ of observations with a gradual thermal gradient. All 6 rations used in the 2 prior experiments were included (Table 1), with 3 groups of fish for each ration level. A fourth group was added for the lowest ration treatment because a fish had died in one of the existing groups. A fish in this additional group also died. Thus, this treatment used 2 groups of 5 fish and 2 groups with 4 fish. Expt 3 fish were from the 1993 year class, with a total length ranging from 95 to $171 \mathrm{~mm}(\bar{x}=117)$.

For data analysis in Expt 3, an image analysis system was used during videotape playback. The position of each fish was marked with a cursor and entered into a computer as $x, y$ coordinates. Positions were noted every min for $10 \mathrm{~min}$, with 6 sets of observations on each day. Using the 15 thermistor readings and assuming a linear change in temperature from one thermistor to the next, we calculated the corresponding temperature for the observed depth of each fish. This method allowed us to more precisely determine the thermal experience of the group. Activity levels and activity ambits for Expt 3 were determined in the same manner as in Expts 1 and 2.

Effects of ration and temperature on growth. To verify our assumption that lower temperatures were energetically beneficial for fish on low rations, we measured growth of pollock acclimated to either 2.5 or $8.5^{\circ} \mathrm{C}$, with 23 fish tested at each temperature. The initial size of the fish was balanced between treatments to control for any size influence on growth. The mean initial length was $180 \mathrm{~mm}$ (range: 143 to $214 \mathrm{~mm}$ ) for fish held at $2.5^{\circ} \mathrm{C}$, and $174 \mathrm{~mm}$ (range: 139 to $213 \mathrm{~mm}$ ) for fish held at $8.5^{\circ} \mathrm{C}$. Fish were held individually in $150 \mathrm{l}$ tanks and randomly assigned a ration of 0 to $10 \%$ 
BW $d^{-1}$. For the low temperature treatment, the temperature was reduced over $48 \mathrm{~h}$ from 8.5 to $2.5^{\circ} \mathrm{C}$. Temperatures subsequently remained within $\pm 1.0^{\circ} \mathrm{C}$ of the target temperature. For both temperatures, fish were not fed for the first $48 \mathrm{~h}$. Then they were fed the prescribed ration on a daily basis. The food was divided into pieces of equal weight. Any pieces remaining in a tank on the following day were counted and removed; their estimated weight was subtracted from the initial weight to determine the actual ration consumed by each fish. After $12 \mathrm{~d}$ the fish were removed and measured.

Statistical analysis. We used repeated measures ANOVAs to test for differences in the behavioral responses by the pollock in Expts 1 and 2. The tested behaviors were the mean vertical position in the water column, activity level, activity ambit, and the percentage of time spent in the cold water layer when a thermocline was present. Ration level was a between groups factor for each ANOVA, with 3 groups comprising the replicates for each ration. The day of the experiment was a within groups factor. For the percentage of time spent in cold water, which could be measured only under stratified conditions, only Days 3 and 4 were included in analysis. For each factor combination, behavioral responses within a group were averaged prior to analysis. Homogeneity of variance tests (Bartlett's) indicated that parametric tests were appropriate for all response variables except the time spent in cold water in Expt 1. Following log-transformation, this variable also had homogeneous variances within cells. Tukey multiple comparisons tests were used to distinguish differences among means.

In Expt 3, average vertical positions and activity indices were analyzed similarly to the above methods, using repeated measures ANOVAs with ration level as a between groups factor and day of experiment as a within groups factor. For stratified conditions, the vertical positions measured with image analysis were converted to the corresponding temperatures, based on the thermistor records for each taping session. The tape analysis provided 300 temperature records for each group on each of the 3 days of thermal stratification. The average temperature experience of the group was calculated for each observation period and the effect of ration compared in a 1-way ANOVA for each day of stratification.

For the experiment testing interactive effects of temperature and ration on growth, the daily percentage increase in weight was compared in an analysis of covariance, with temperature as the main effect and average consumed ration as a covariate. Initial size of each fish was also included as a covariate to address size effects on growth.

\section{RESULTS}

\section{Effects of ration on growth and condition}

Ration had the predicted consequence for growth, with the effects of food deprivation similar at the same rations repeated across experiments (Fig. 1). At the highest ration (fish were offered $10 \% \mathrm{BW} \mathrm{d}^{-1}$ for $10 \mathrm{~d}$ ), weight increased by an average of $33.3 \%$. This ration was assumed to be an ad libitum level, since the food continued to be available until the next feeding (pellets sank to the bottom of the tank and were often consumed later by the fish) but was never fully consumed. Thus, consumption and growth rates for the highest ration treatment approached the maximum possible under laboratory conditions at an average temperature of about $12^{\circ} \mathrm{C}$. The second highest ration $\left(2.5 \% \mathrm{BW} \mathrm{d}^{-1}\right.$ for $10 \mathrm{~d}$ ), while still yielding positive growth, closely approached a maintenance level. The next lowest ration $\left(0.5 \% \mathrm{BW} \mathrm{d}^{-1}\right.$ for $\left.10 \mathrm{~d}\right)$ was below maintenance, with fish showing a loss of weight. Under the starvation treatments, weight markedly decreased $(\bar{x}=$
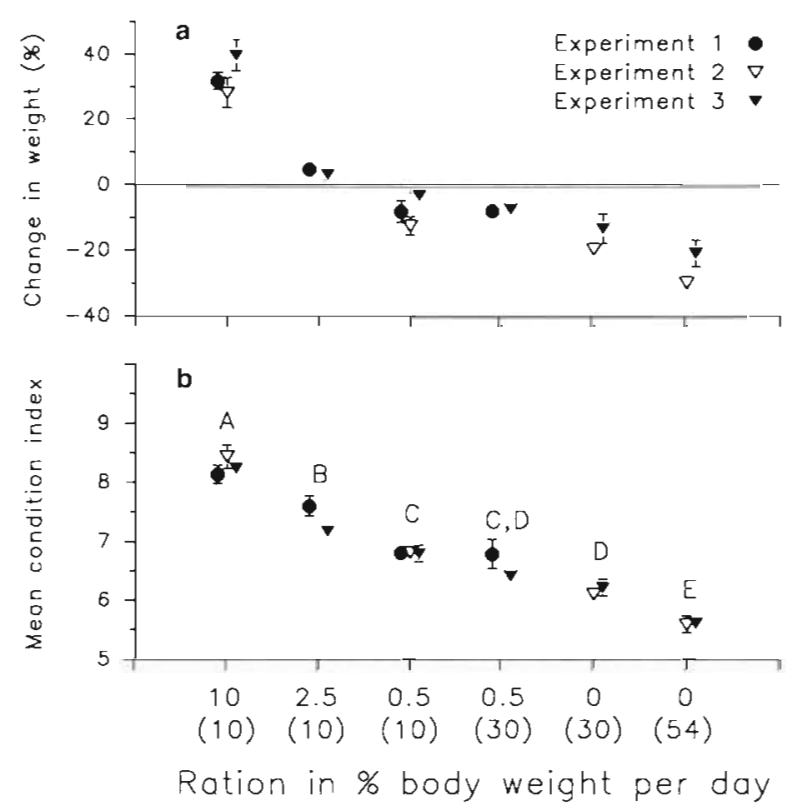

Fig. 1. Theragra chalcogramma. (a) Absolute change in mean body weight during the pre-observation period and (b) mean condition index at the end of this period, for groups of juvenile pollock held on varying ration levels in each experiment. Symbols represent mean of group means; error bars are standard errors. Each ration treatment included 3 groups of 5 fish each except the lowest ration in Expt 3, which had 4 groups. Ration levels indicate the daily \% body weight provided, with number of days in parentheses. Condition indices were calculated as (wet weight, $\mathrm{g}$ ) $\times\left(\right.$ total length, $\mathrm{mm}^{-3} \times 10^{6}$. Letters designate results of Tukey multiple comparisons tests on combined means for each ration, with different letters indicating significantly different condition 
$-16.5 \%$ at $30 d_{i}-25.3 \%$ at 54 d). Growth responses on the various ration levels resulted in significantly different condition indices ( 1 -way ANOVA on data from all 3 experiments combined; $F=150.3 ; p<0.001$; Fig. 1).

\section{Effects of ration on vertical distribution - sharp thermal gradient}

During the first $2 \mathrm{~d}$ of observations in Expts 1 and 2, when the water column was isothermal, fish occurred throughout the water column, resulting in an average vertical position at about mid-level of the tank (Fig. 2). On Days 3 and 4 of both experiments, a sharply defined thermocline was formed just below the midlevel of the tank. Stratification of the water column caused the fish to avoid cold water and move upward, with the fish, on average, occurring above the thermocline in both Expts 1 and 2 (repeated measures ANOVA: $F$ for day factor in Expt $1=17.86, \mathrm{p}<0.001$; $F$ for Expt $2=9.96, p<0.001$ ). This general avoidance of cold water was consistent with previous results for juvenile walleye pollock under sharply stratified conditions (Olla \& Davis 1990. Sogard \& Olla 1993).

Although the general pattern for fish held at all rations was to move upward to avoid cold water, occupancy of cold water increased as ration decreased from high to intermediate levels (Fig. 3). However, in Expt 2, under conditions of zero rations (no food for 30 and 54 d), occupancy of cold water decreased to levels similar to those observed at the highest ration. In both experiments, the time spent in cold water was signifi-

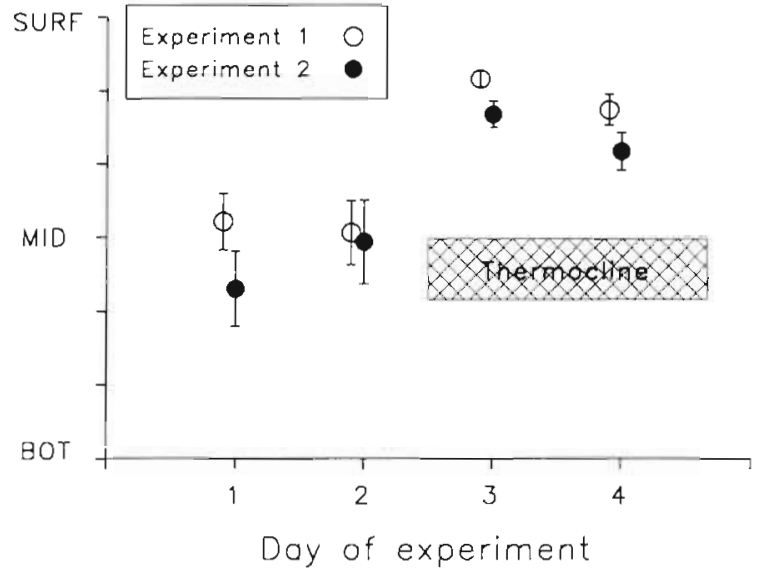

Fig. 2. Theragra chalcogramma. Mean vertical positions on each day of Expts 1 and 2. Vertical axis represents distance from the surface to the bottom of experimental tanks. Plotted values are means and standard errors of group means; $n=12$ groups in each experiment. Days 1 and 2 had isothermal water columns. On Days 3 and 4 , there was a sharp thermal transition from 8.5 to $2.5^{\circ} \mathrm{C}$ positioned at around mid-depth of the tank cantly different among ration treatments (repeated measures ANOVA: $F$ for Expt $1=7.58, \mathrm{p}=0.01 ; F$ for Expt $2=9.67, \mathrm{p}=0.005$ )

On the second day of thermal stratification (Day 4), a slight weakening of the thermocline was evident (Fig. 3), with the fish in Expt 1 spending more time in cold water on Day 4 than on Day 3 (repeated measures ANOVA: $F=6.12, p=0.038$ ). In Expt 2, however, although thermal stratification was similar to that in Expt 1, vertical distribution did not differ between the 2 days of stratification $(F=0.09, \mathrm{p}=0.765$ ).

Ration also influenced the pattern of dive durations beneath the thermocline in Expts 1 and 2. Dive durations for fish held under the highest ration were all relatively short (Fig. 4), with only $14 \%$ exceeding $30 \mathrm{~s}$. In contrast, at an intermediate ration of $0.5 \% \mathrm{BW} \mathrm{d}^{-1}$ for $30 \mathrm{~d}, 52 \%$ of the dives exceeded $30 \mathrm{~s}$ (Fig 4), with some individuals spending over $4 \mathrm{~min}$ of a $10 \mathrm{~min}$

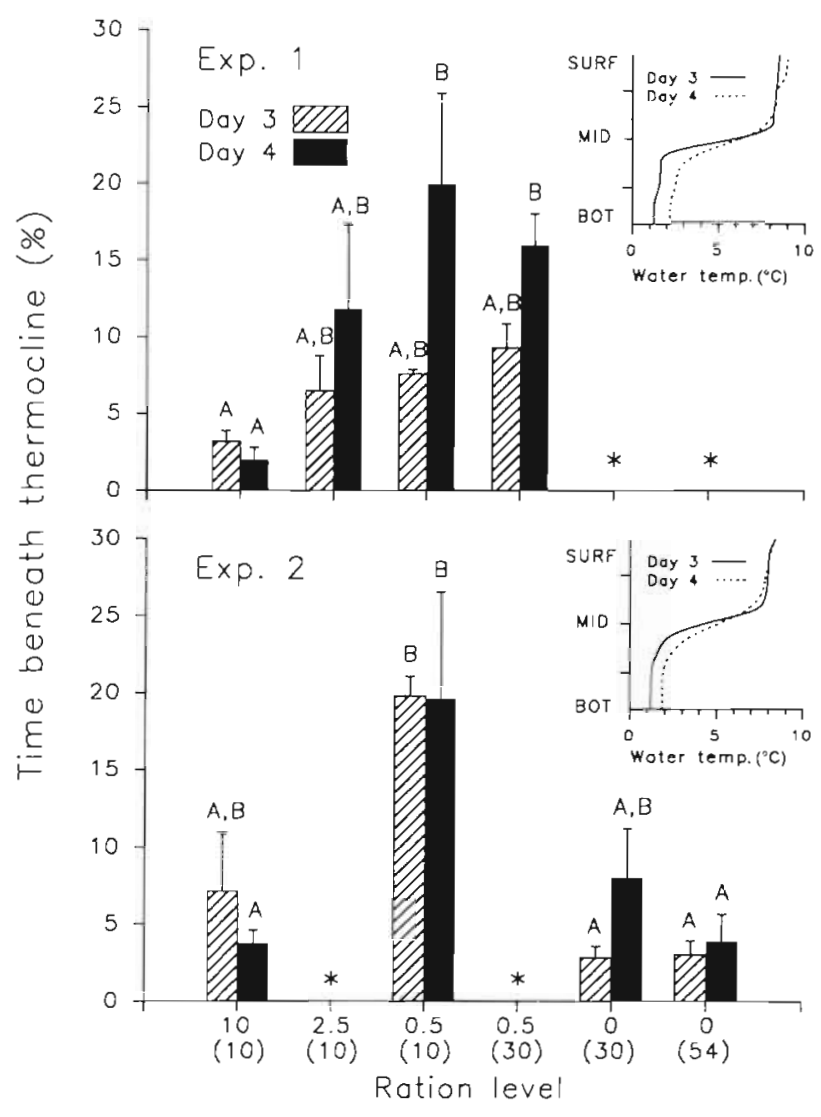

Fig. 3. Theragra chalcogramma. Percentage of time spent in cold water layer beneath an experimentally induced thermocline by walleye pollock maintained on varying rations on Days 3 and 4 in Expts 1 and 2. Bars indicate mean of the 3 group means for each ration level; error bars are standard errors. "No data. Insets display average temperature profiles with depth for each experiment. Ration levels as in Fig. 1. Letters designate results of Tukey multiple comparisons tests, with different letters indicating significantly different times in cold water 


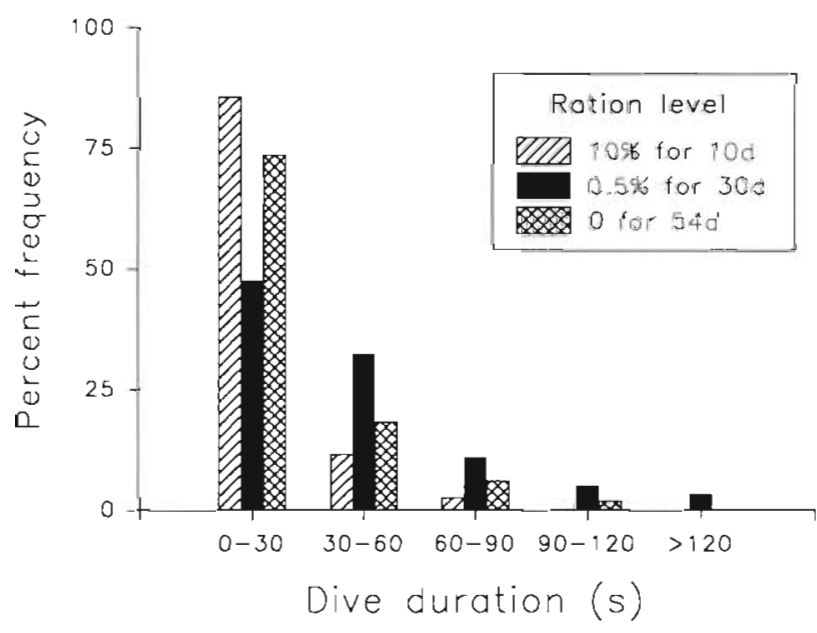

Fig. 4. Theragra chalcogramma. Frequency distribution of dive durations (in seconds) for 3 of the ration levels tested in Expts 1 and 2. A dive was timed from when an individual descended beneath the thermocline until it returned to the upper water layer. Dives were divided into $30 \mathrm{~s}$ intervals, with all dives $>120$ s comprising the last category

observation trial in cold water. At zero rations, the pattern of dive durations was similar to that observed at high rations, with only $26 \%$ exceeding $30 \mathrm{~s}$ under the longest period of starvation (54 d; Fig. 4).

\section{Effects of ration on vertical distribution- gradual thermal gradient}

In Expt 3 we provided juveniles with the opportunity to move into varying water temperatures by establishing a more gradual thermal transition and then determining the precise depth and corresponding temperature at which each fish occurred during a point in time. Similar to Expts 1 and 2, the average vertical position was at mid-depth under isothermal conditions, but moved upward when a gradual thermal gradient was created on Day 3, indicating initial avoidance of cold water. The average temperatures occupied on Day 3 did not differ among the 6 ration treatments, ranging from 7.3 to $9.1^{\circ} \mathrm{C}$ (Fig. 5; 1 -way ANOVA: $F=0.84, p=$ 0.542 ). By Days 4 and 5, with the thermal gradient still extant, fish from the highest ration treatment remained at warmer temperatures, consistent with the observations in Expts 1 and 2. However, in contrast to what we observed under conditions of an abrupt thermocline in Expts 1 and 2, fish that had been held on low rations occupied colder temperatures on Day 4 (1-way ANOVA: $F=4.08, p=$ 0.019 ). This relationship intensified by Day 5 , with a difference in temperature occupancy of 3 to $4{ }^{\circ} \mathrm{C}$ between fish that had been held at higher rations and those on zero rations (1-way ANOVA: $F=5.11$, $\mathrm{p}=0.008$ ).

Based on temperature effects on $\mathrm{O}_{2}$ consumption presented by Paul (1986), we calculated the differences in metabolic rates for each ration treatment relative to the highest ration (mean temperature on Day 5 $=7.3^{\circ} \mathrm{C}$ ), which presumably reflected behavior of juvenile pollock under the ideal conditions of unlimited food. Under this comparison, fish on the second highest ration $\left(2.5 \% \mathrm{BW} \mathrm{d}^{-1}\right.$ for $10 \mathrm{~d}$ ) experienced an energetic cost of $9.0 \%$, due to their occurrence in warmer water. Estimated energetic benefits of 11.2, 6.7, 27.0, and $33.8 \%$ were gained with increased occupancy of cold water by subsequently lower ration levels, respectively.

Frequency distributions of the temperature positions obtained for each group suggested that mean temperature occurrence of each group was not attained by restricting movement to that particular temperature (Fig. 6). Instead, fish on all rations continued to move throughout the experimental tank, but spent differing

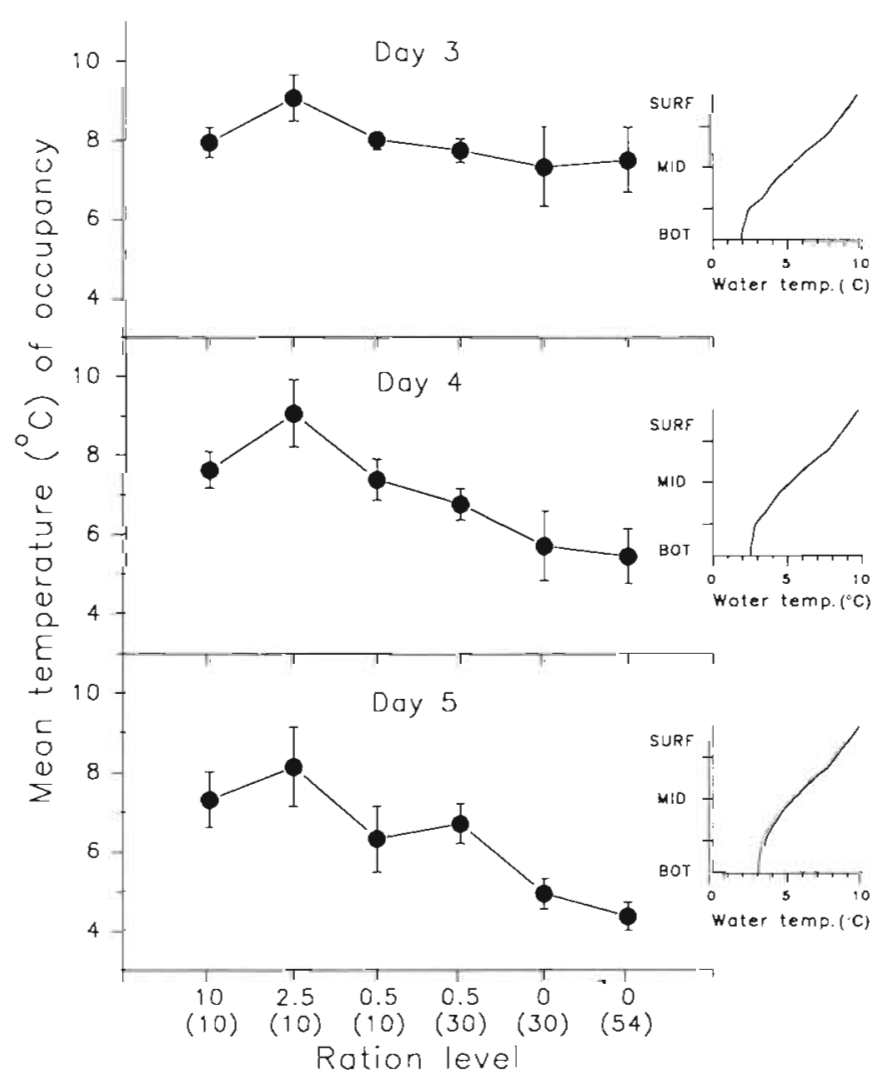

Fig. 5. Theragra chalcogramma. Mean temperatures occupied by walleye pollock held on varying rations for each day of stratification in Expt 3 (Days 1 and 2 were isothermal). Plotted values represent mean of group means, with 3 groups in each ration treatment except the lowest ration, which had 4 groups. Insets display average temperature profile on each day. Ration levels as in Fig. 1 

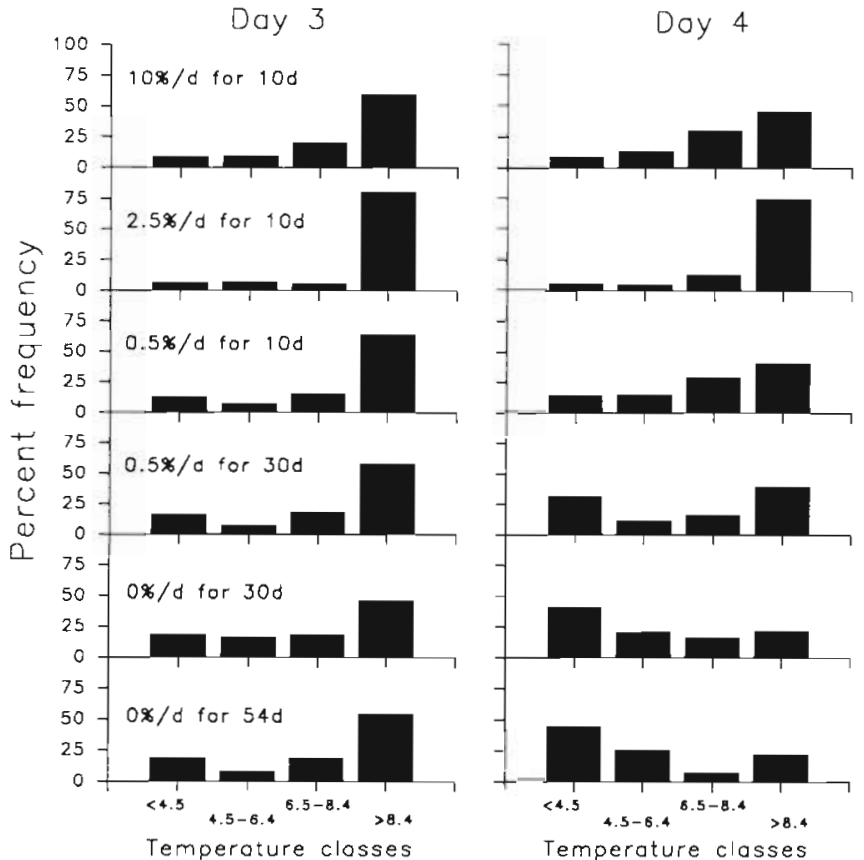

proportions of time in the various thermal layers. Across the $3 \mathrm{~d}$ of stratified conditions, fish in all ration groups spent increasing amounts of time in colder water layers. The transition from occupying primarily surface waters to residence in deeper, colder layers was particularly striking as ration level decreased. By Day 5, fish in the lowest ration groups were spending, on average, $74 \%$ of their time in temperatures $<4.5^{\circ} \mathrm{C}$. Intermediate ration groups, however, spent similar proportions of time in surface and bottom layers, resulting in an intermediate mean temperature (Fig. 5).

\section{Effects of ration on activity}

Across the 3 experiments, there was a general pattern of intermediate motor activity levels for fish on the highest ration, and then increased activity as ration initially declined, followed by a marked decrease in activity as ration declined to zero levels (Fig 7). The ration effect was statistically significant in Expts 2 and 3 and nearly significant in Expt 1 (repeated measures ANOVAs: $F$ for Expt $1=3.56, \mathrm{p}=0.067 ; F$ for Expt $2=$ 5.96, $p=0.019 ; F$ for Expt $3=15.69, p<0.001$ ). Across all rations, fish typically swam continuously but at different rates; periods of passive sinking were not observed.

The effect of ration on activity ambit followed a similar but even more striking pattern, with the ambit of fish in the highest ration treatment dropping to the level of fish in the zero ration treatments (Fig 7). Ambit indices were significantly different among ration levels

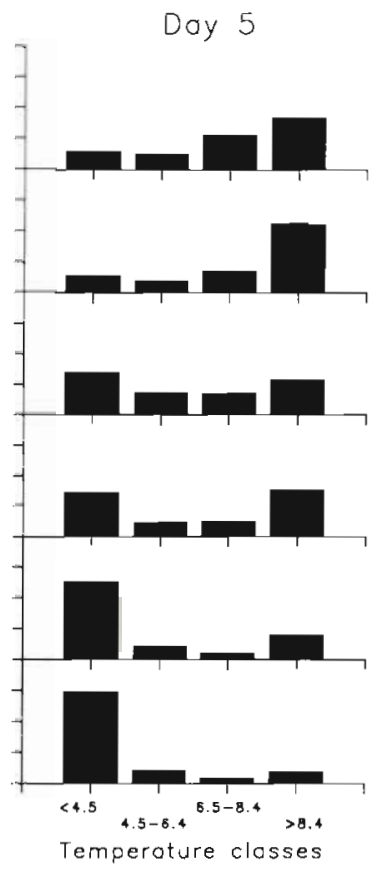

Fig. 6. Theragra chalcogramma. Percentage frequency distributions of temperature positions on each day of stratification in Expt 3. Positions were assigned to 4 categories approximating 4 horizontal layers in experimental tanks, with temperatures progressing from colder water at the bottom to warmer at the surface. Percentages are means of group means, with 300 fish positions determined for each group on each day. Ration treatments are presented in order from highest $10 \% \mathrm{BW}$ $\mathrm{d}^{-1}$ for $10 \mathrm{~d}$ ) to lowest (no food for 54 d) for each day
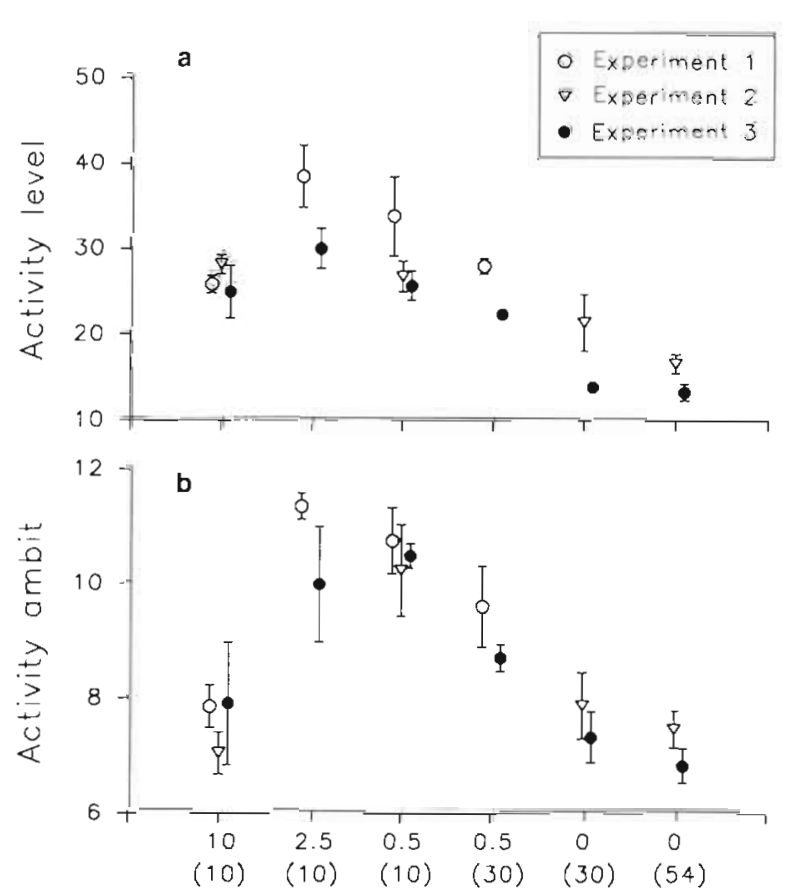

Ration in $\%$ body weight per day

Fig. 7. Theragra chalcogramma. Mean indices of (a) motor activity and (b) ambit of activity for each ration treatment in each vertical distribution experiment. Activity level was calculated as number of crossings from one block to another during a 5 min period, and ambit was calculated as number of different blocks (out of a possible 16) occupied by a fish durIng a $5 \mathrm{~min}$ period. Symbols indicate mean of group means; error bars are standard errors. Ration levels as in Fig. 1 
in all 3 experiments (repeated measures ANOVAs; $F$ for Expt $1=9.33, \mathrm{p}=0.005 ; F$ for Expt $2=6.14, \mathrm{p}=$ $0.018 ; F$ for Expt $3=5.74, p=0.005$ ). Thus, fish on the highest ration and the 2 zero rations searched a low proportion of the available area during an observation, while fish on intermediate rations moved through a greater portion of the tank, suggesting intensified searching behavior.

\section{Interactive effects of temperature and ration on growth}

To address the potential extent of energetic benefits accruing to food-deprived fish that select colder water temperatures, we compared growth rates of juvenile pollock under varying rations at 2 different temperatures $\left(2.5\right.$ and $\left.8.5^{\circ} \mathrm{C}\right)$. Temperature had an obvious effect on consumption; the maximum ration consumed by fish held at $2.5^{\circ} \mathrm{C}$ was $1.8 \% \mathrm{BW} \mathrm{d}^{-1}$, whereas the maximum for fish held at $8.5^{\circ} \mathrm{C}$ was $4.9 \% \mathrm{BW} \mathrm{d} \mathrm{d}^{-1}$ (Fig. 8). Daily growth was significantly higher at the
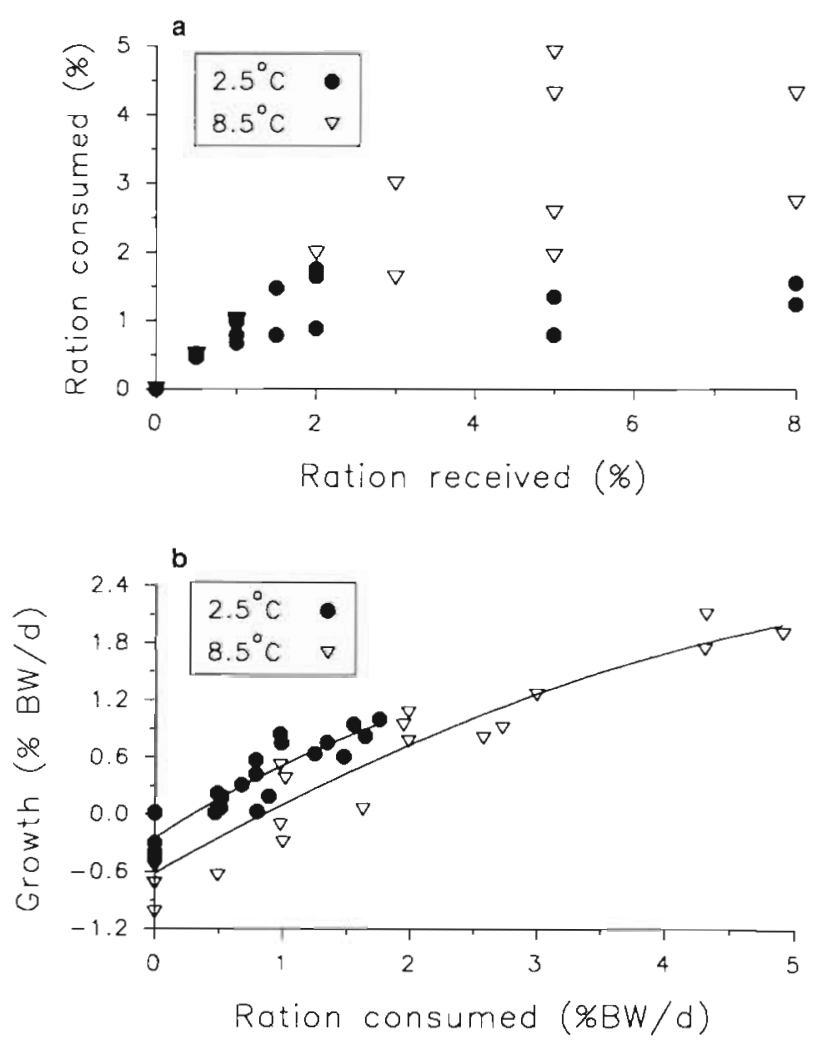

Fig. 8. Theragra chalcogramma. (a) Ration consumed relative to ration provided and (b) growth in \% body weight per day relative to ration consumed for juvenile walleye pollock maintained on varying rations at either 2.5 or $8.5^{\circ} \mathrm{C}$. Fish were held individually for $12 \mathrm{~d}$. Regression lines are based on $2 \mathrm{nd}$ order equations providing the best fit to the data $\left(\mathrm{r}^{2}\right.$ for $2.5^{\circ} \mathrm{C}=0.84$, $r^{2}$ for $8.5^{\circ} \mathrm{C}=0.90$ ) lower temperature, especially at the lower levels of food intake (Fig. 8; ANCOVA: $F$ value for temperature effect $=27.7, p<0.001$ ). Initial size did not affect growth rate across the size range used in this experiment (ANCOVA: $F=0.5, p=0.5$ ). For the fish maintained on starvation rations (no food, $\mathrm{n}=6$ for each temperature), weight loss for fish held at $8.5^{\circ} \mathrm{C}$ was $64 \%$ greater than for fish held at $2.5^{\circ} \mathrm{C}$.

We predicted that warmer temperatures would support faster growth when ration level was high. However, we were not able to verify this effect due to the influence of temperature on consumption and the resulting lack of high values of consumption by fish held in colder water. Fish held at $2.5^{\circ} \mathrm{C}$ never consumed over $2 \% \mathrm{BW} \mathrm{d}^{-1}$, despite receiving up to $8 \%$ $\mathrm{BW} \mathrm{d}^{-1}$ (Fig. 8). The growth contrasts at lower rations, however, clearly supported our assumption that lower water temperatures are beneficial to fish experiencing low food availability.

\section{DISCUSSION}

The results of this study have demonstrated that juvenile walleye pollock possess a wide breadth of behaviors to deal with variation in the availability of food resources. When food was not limited, fish restricted distribution primarily to the warmer surface waters under stratified conditions, had intermediate levels of motor activity, and exhibited a limited ambit of activity, suggesting that the motivation to search for food was relatively low. A similar pattern was observed in an earlier study on juvenile cod Gadus morhua, where well-fed fish exhibited slower swimming speeds than fish provided with intermediate rations (Björnsson 1993). Likewise, adult sablefish Anoplopoma fimbria fed to satiation spent more time resting on the bottom and were less responsive to bait odors than fish deprived of food for 1 or 4 d (Lokkeborg et al. 1995).

Lowered activity levels and decreased responsiveness to food can provide corollary advantages to wellfed individuals. Energetic costs are substantially reduced by lower swimming speeds (Ware 1975, Bjönsson 1993). Additionally, restricting food searching activity may also lower an individual's risk of detection by predators and allow increased vigilance, suggesting that the behavior of satiated fish is consistent with studies demonstrating trade-offs between different foraging behaviors and predation risk (Lima \& Dill 1990, Milinski 1993).

As the ration received by walleye pollock declined to just above maintenance level (the second highest ration), motor activity and ambit increased. Higher activity was presumably indicative of higher motivation to feed and increased searching behavior by fish 
still in a generally healthy state, based on condition indices. Fish in this treatment did not make use of cold water as an energetic refuge. In fact, the average temperature of occurrence in Expt 3 suggested that fish were acquiring an energetic cost by spending most of their time in warmer surface waters. This behavior indicated high searching activity but continual return to surface waters, where they had previously received all food while in the laboratory.

With a further decline in ration to intermediate levels, motor activity and ambit remained high, fish made more extensive excursions into cold water under the sharply stratified conditions of Expts 1 and 2, and spent more time in colder water temperatures in Expt 3. Movements through a sharp thermocline were typically directed in appearance (head down on descent. head up on ascent), with fish often diving to the bottom of the tank, swimming around the bottom for several seconds, then rapidly returning to the upper layer. In the gradual gradient of Expt 3, fish on intermediate rations continued to display active movement throughout the tank.

The greater occupancy of cold water by fish on intermediate rations could have provided energetic benefits. Although we did not measure metabolic rates and do not have estimates for the increase in costs associated with higher levels of searching activity, we can make some estimates of the metabolic benefits of movement into cold water based on previously published values. Employing equations for the cooling half-time and instantaneous body temperature for fish (Spigarelli et al. 1977), juvenile walleye pollock moving from 8.5 to $2^{\circ} \mathrm{C}$ would experience a 1 to $2^{\circ} \mathrm{C}$ drop in body temperature within 10 to $20 \mathrm{~s}$. With a decline in body temperature, we would assume a simultaneous decline in metabolic rate (Moffitt \& Crawshaw 1983, Black et al. 1991), with average metabolic rate a function of the average temperature experienced (Hokanson et al. 1977, Medvick 1979, Cox \& Coutant 1981, Diana 1984. Vondracek et al. 1989). Based on results of an earlier study on juvenile walleye pollock that showed a sharp decrease in metabolic rate $\left(Q_{10}=6.04\right)$ as temperature decreased from 7.5 to $1^{\circ} \mathrm{C}$ (Paul 1986), and with fish at intermediate rations in the present experiments spending from 8 to $20 \%$ of the time in cold water, we calculated a potential decrease in metabolic rate of 5.2 to $12.9 \%$. While this appears to be a modest reduction, it may be significant for fish experiencing low food availability and zero or negative growth for extended periods of time. However, in the field, juvenile pollock will have to traverse greater distances to reach cold water than what was provided by the $2.5 \mathrm{~m}$ depth of our experimental tanks, and the energetic benefits of cold water will necessarily be balanced by the costs of vertical movement through the water column.
When walleye pollock juveniles were held for long periods without food, motor activity and ambit decreased, reflecting a decrease in food searching behavior despite presumably intense hunger. Lower activity would decrease energy expenditures, which might be an adaptation to delay starvation. Juvenile cod displayed a similar decline in activity when food was severely limited (Björnsson 1993). Aside from a decrease in activity, a decrease in temperature distribution would also be an adaptive response for starved fish. In the presence of a sharp thermocline (Expt 2), starved fish avoided cold water and remained in the warmer surface layer. However, in Expt 3, in the presence of a more gradual thermal gradient, there was a clear decrease in the temperature at which fish were distributed. Fish that had been deprived of food for $54 \mathrm{~d}$ were found, on average, at temperatures 3 or $4^{\circ} \mathrm{C}$ colder than fish held at the highest rations.

The avoidance of cold water by the lowest ration groups in Expt 2 was potentially related to the severity of temperature change at the thermocline. The numerous changes in body tissues and biochemistry that accompany starvation (Lowery \& Somero 1990, Pastoureaud 1991, Méndez \& Wieser 1993) may have limited the fishes' physiological capacity for dealing with the precipitous temperature changes encountered in crossing the thermocline. The gradual thermal gradient in Expt 3 allowed fish to lower body temperature more moderately and to a less extreme colder temperature. Further, if the temperature of acclimation (in holding tanks prior to experiments) had been lower, we expect that avoidance temperatures would have been lower and fish would have more readily crossed a sharp thermocline into $2^{\circ} \mathrm{C}$ water. The optimal temperature for physiological functions in most fishes spans a 'zone of efficient operation' rather than forming a sharp peak (Crawshaw 1977). This zone varies with acclimation temperature and narrows in starving individuals (Woiwode \& Adelman 1992), resulting in decreasing energetic benefits of very cold water.

Alternatively, but much less likely, starvationinduced changes in specific gravity in Expt 2 may have limited the capability of fish to swim downward through the abrupt density difference associated with a sharp thermocline. However, little is known about the effect of starvation on specific gravity in juvenile fish and how this might affect motility and the ability to avoid or select particular environments. Evidence of a relationship is limited to larval stages and appears to be contradictory, with poor feeding conditions causing both decreases (herring Clupea harengus, and plaice Pleuronectes platessa: Blaxter \& Ehrlich 1974; sea bass Dicentrarchus labrax: Katavić 1986) and increases (walleye pollock: Davis \& Olla 1992) in specific gravity. Support for an alternative hypothesis of juvenile wall- 
eye pollock being precluded from moving through sharp density gradients because of starvation-induced changes in specific gravity awaits further research and is beyond the scope of the present study. However, fish on starvation rations in the gradual thermal/density gradient of Expt 3 appeared fully capable of maintaining particular depths, and passive sinking or rising was not observed. The steady decrease in average temperatures across the $3 \mathrm{~d}$ of thermal stratification in Expt 3 also suggests that active temperature responses were more influential in the fishes' behavior than passive buoyancy responses.

The distribution of starving pollock in the gradual thermal gradient of Expt 3 demonstrated increasing energetic benefits across the $3 \mathrm{~d}$ of stratification. By the third day under stratified conditions, occupancy of cold water resulted in estimated energetic savings of 27.0 and $33.8 \%$ for the 2 starvation ration levels, compared to the metabolic rates of fish on the highest ration. Thus, when approaching starvation, walleye pollock occupied temperatures that provided substantial reductions in energetic expenditures. Reduced activity presumably provided further conservation benefits. As with the highest ration groups, reduced activity could also lower encounter rates with predators, which would be especially relevant for fish in poor physical condition with potentially diminished predator avoidance capabilities (Ivlev 1961, Booman et al. 1991).

The results of Expt 3 provide convincing support for a bioenergetics hypothesis of vertical distribution; fish experiencing low food availability clearly adjusted distribution to lower temperatures. The relevance of this finding, however, depends on the extent of food deprivation encountered by juvenile walleye pollock under natural conditions. Bailey's (1989) study demonstrated that fish with high recent foraging success remained in the upper water column, consistent with our experimental results. Less successful foragers were more likely to move beneath the thermocline. Since the growth values reported by Bailey (1989) for pollock at sites with lower food densities indicated that these individuals were still experiencing positive growth, their physical condition was probably more similar to the intermediate ration treatments of our study than to the fish held on starvation rations. Thus, their movement into cold water could reflect increased searching behavior, with energetic benefits dependent on the costs of increased motor activity associated with searching a greater range of the water column. We do not know if walleye pollock in the field reach the levels of poor physical condition tested in this study. A thorough test of bioenergetic responses under natural conditions would require monitoring of activity and observations of fish approaching starvation levels of physical condition. It is not currently known if walleye pollock encounter such prolonged periods of low food availability in the sea

For invertebrate species that display vertical migration, predator avoidance has clearly been supported as an underlying causal factor for this behavior. The complete dismissal of a bioenergetics hypothesis (see Lampert 1989) may be unwarranted, however. Rejection of any metabolic advantage for vertically migrating invertebrates has typically ignored the crucial component of food limitation (Stich \& Lampert 1984, Lampert et al. 1988, Ohman 1990. Guisande et al. 1991). Our results clearly demonstrate that restricted food availability modifies vertical distribution in the absence of any immediate predation threat. In both fishes and invertebrates, interactive effects of temperature on food consumption, metabolic rates, conversion rates, conversion efficiency, and other basic physiological processes converge on an optimal temperature for individual growth. Temperatures below this optimum will be beneficial only under food-limited conditions, as emphasized by Brett (1971) for fishes, and Geller (1986) and Büns \& Ratte (1991) for zooplankton. Dini \& Carpenter (1992) suggested a hierarchy of causal factors for vertical migration in zooplankters, with predator avoidance foremost, and energy conservation incorporated when food availability is low. Levy (1990) suggested a similar hierarchy for juvenile sockeye salmon. The response of any particular individual may depend on a trade-off between the likelihood of predation in different water layers and the bioenergetic costs of different temperatures.

For juvenile walleye pollock, predators may have less relevance in effecting vertical migration behavior. According to allocation theory, individuals in the best physical condition can most afford whatever costs are associated with predator avoidance (Lima \& Dill 1990). The continued residence of well-fed pollock in the surface layers above the thermocline, e.g. in this study and in Bailey's (1989), suggests that deeper layers do not significantly reduce predation risk. In north Pacific waters, juvenile walleye pollock are a major prey for a wide variety of vertebrate predators. Frost \& Lowry (1981) listed 11 species of marine mammals, 13 species of birds, and 10 species of fishes that are pollock predators. Predation risk occurs throughout the water column, but may actually increase in deeper layers due to the presence of cannibalistic adult pollock, which typically concentrate beneath the thermocline (Bailey 1989, Sinclair et al. 1993). Compared to other predators, adult pollock are by far the greatest source of predation mortality for juveniles (Livingston 1993). Dwyer et al. (1987) estimated that 402 billion young-of-the-year pollock are consumed by adults on an annual basis in the Bering Sea. Thus, migration beneath the thermocline as a mechanism of avoiding 
predators does not appear tenable for juvenile walleye pollock.

In summary, juvenile walleye pollock have the capability of initiating energy-conserving behaviors when foraging conditions are depressed. The apparent increased searching behavior of fish at intermediate levels of physical condition demonstrates the flexibility of this species in responding to variability in food resources. In the sea, these behavioral adaptations presumably allow the fish to intensify searching activity and improve their foraging success when food levels initially decline, but lower energetic costs and extend survival during severe periods of low food availability.

Acknowledgements. We thank Shelly Clouse, Michelle McConnell, Mara Spencer, and Rich Titgen for assistance with laboratory experiments and videotape analysis. Rich Titgen designed the computer program used for temperature calculations in Expt 3. Rom Lipcius and Kevin Bailey provided valuable comments on an earlier draft of the manuscript. This paper is a contribution of NOAA's Fisheries Oceanography Coordinated Investigations, FOCI-0269

\section{LITERATURE CITED}

Bailey KM (1989) Interaction between the vertical distribution of juvenile walleye pollock Theragra chalcogramma in the eastern Bering Sea and canmbalism. Mar Ecol Prog Ser 53:205-213

Bevelhimer MS, Adams SM (1993) A bioenergetics analysis of diel vertical migration by Kokanee salmon, Oncorhynchus nerka. Can J Fish Aquat Sci 50:2336-2349

Björnsson B (1993) Swimming speed and swimming metabolism of Atlantic cod (Gadus morhua) in relation to available food: a laboratory study. Can J Fish Aquat Sci 50 . $2542-2551$

Black MC, Millsap DS, McCarthy JF (1991) Effects of acute temperature change on respiration and toxicant uptake by rainbow trout, Salmo gairdneri (Richardson). Physiol Zool 64:145-168

Blaxter JHS, Ehrlich KF (1974) Changes in behaviour during starvation of herring and plaice larvae. In: Blaxter JHS (ed) The early life history of fish. Springer-Verlag, Berlin, p 575-588

Booman C, Folkvord A, Hunter JR (1991) Responsiveness of starved northern anchovy Engraulis mordax larvae to predatory attacks by adult anchovy. Fish Bull US 89: $707-711$

Brandt SB (1993) The effect of thermal fronts on fish growtha bioenergetics evaluation of food and temperature. Estuaries 16:142-159

Brett JR (1.971) Energetic responses of salmon to temperature. A study of some thermal relations in the physiology and freshwater ecology of sockeye salmon (Oncorhynchus nerka). Am Zool 11:99-113

Büns M, Ratte HT (1991) The combined effects of temperature and food consumption on body weight, egg production and developmental time in Chaoborus crystallinus de Geer (Diptera: Chaoboridae). Oecologia 88:470-476

Cossins AR, Bowler K (1987) Temperature biology of anmals. Chapman \& Hall, London
Cox DK, Coutant CC (1981) Growth dynamics of juvenile striped bass as functions of temperature and ration. Trans Am Fish Soc 1 10:226-238

Crawshaw LI (1977) Physiological and behavioral reactions of fishes to temperature change. J Fish Res Bd Can 34: $730-734$

Crowder LB, Magnuson JJ (1983) Cost-benefit analysis of temperature and food resource use: a synthesis with examples from the fishes. In: Aspey WP, Lustick SI (eds) Behavioral energetics: the cost of survival in vertebrates. Ohio State University Press, Columbus, p 189-221

Davis MW, Olla BL (1992) Comparison of growth, behavior and lipid concentrations of walleye pollock Theragra chalcogramma larvae fed lipid-enriched, lipid-deficient and field-collected prey. Mar Ecol Prog Ser 90:23-30

Diana JS (1984) The growth of largemouth bass, Micropterus salmoides (Lacepede), under constant and fluctuating temperatures. J Fish Biol 24:165-172

Dini ML, Carpenter SR (1992) Fish predators, food availability and diel vertical migration in Daphnia. J Plankton Res 14 359-377

Dwyer DA, Bailey KM, Livingston PA (1987) Feeding habits and daily ration of walleye pollock (Theragra chalcogramma) in the eastern Bering Sea, with special reference to cannibalism. Can J Fish Aquat Sci 44:1972-1984

Frost KJ, Lowry LF (1981) Trophic importance of some marine gadids in northern Alaska and their body-otolith size relationships. Fish Bull US 79:187-192

Gatten RE Jr (1974) Effect of nutritional status on the preferred body temperature of the turtles Pseudemys scripts and Terrapene ornata, Copeia 9:912-917

Geller W (1986) Diurnal vertical migration of zooplankton in a temperate great lake (L. Constance): a starvation avoidance mechanism? Arch Hydrobiol 74:1-60

Godin JGJ, Smith SA (1988) A titness cost of foraging in the guppy. Naturn 333:69-71

Gotceitas V, Godin JGJ (1991) Foraging under the risk of predation in juvenile Atlantic salmon (Salmo salar L.): effects of social status and hunger. Behav Ecol Sociobiol 29: $255-261$

Guisande C, Duncan A, Lampert W (1991) Trade-offs in Daphnia vertical migration strategies. Oecologia 87: $357-359$

Hokanson KEF, Kleiner CF, Thorslund TW (1977) Effects of constant temperatures and diel temperature fluctuations on specific growth and mortality rates and yield of juvenile rainbow trout, Salmo gairdneri. J Fish Res Bd Can 34: $639-648$

Ivlev VS (1961) Experimental ecology of the feeding of fishes. Yale University Press, New Haven

Javaid MY, Anderson JM (1967) Influence of starvation on selected temperature of some salmonids. J Fish Res Bd Can 24:1515-1519

Katavić I (1986) Diet involvement in mass mortality of sea bass (Dicentrarchus labrax) larvae. Aquaculture 58:45-54

Lampert W (1989) The adaptive significance of diel vertical migration of zooplankton. Funct Ecol 3:21-27

Lampert W, Schmitt RD, Muck P (1988) Vertical migration of freshwater zooplankton: test of some hypotheses predicting a metabolic advantage. Bull Mar Sci 43:620-640

Lazzari CR (1991) Temperature preference in Triatoma infestans (Hemiptera: Reduviidae). Bull Entomol Res 81. $273-276$

Levy DA (1990) Sensory mechanism and selective advantage for diel vertical migration in juvenile sockeye salmon, Oncorhynchus nerka. Can J Fish Aquat Sci 47 : 1796-1802 
Lima SL, Dill LM (1990) Behavioral decisions made under the risk of predation: a review and prospectus. Can J Zool 68: $619-640$

Livingston PA (1993) Importance of predation by groundfish, marine mammals and birds on walleye pollock Theragra chalcogramma and Pacific herring Clupea pallasi in the eastern Bering Sea. Mar Ecol Prog Ser 102:205-215

Løkkeborg S, Olla BL, Pearson WH, Davis MW (1995) Behavioural responses of sablefish, Anoplopoma fimbria, to bait odour. J Fish Biol 46:142-155

Lowery MS, Somero GN (1990) Starvation effects on protein synthesis in red and white muscle of the barred sea bass, Paralabrax nebulifer. Physiol Zool 63:630-648

Mac MJ (1985) Effects of ration size on preferred temperature of lake charr Salvelinus namaycush. Environ Biol Fish 14 : $227-231$

Magnhagen C (1988) Predation risk and foraging in juvenile pink (Oncorhynchus gorbuscha) and chum salmon 10 . keta). Can J Fish Aquat Sci 45:592-596

McLaren IA (1963) Effects of temperature on growth of zooplankton, and the adaptive value of vertical migration. $J$ Fish Res Bd Can 20:685-727

Medvick PA (1979) Growth rates of juvenile maomao, Abudefduf abdominalis, at constant and cyclic temperatures. Trans Am Fish Soc 108:293-298

Méndez G, Wieser W (1993) Metabolic responses to food deprivation and refeeding in juveniles of Rutilus rutilus (Teleostei: Cyprinidae). Environ Biol Fish 36:73-81

Milinski M (1984) A predator's cost of overcoming the confusion-effect of swarming prey. Anim Behav 32:1157-1162

Milinski M. (1993) Predation risk and feeding behaviour. In: Pitcher TJ (ed) Behaviour of teleost fishes Chapman \& Hall, London, p 285-305

Moffitt BP, Crawshaw LI (1983) Effects of acute temperatur changes on metabolism, heart rate, and ventilation frequency in carp Cyprinus carpio L. Physiol Zool 56:397-403

Morgan MJ (1988) The influence of hunger, shoal size and predator presence on foraging in bluntnose minnows. Anim Behav 36:1317-1322

Morgan MJ (1993) Ration level and temperature preference of American plaice. Mar Behav Physiol 24:117-122

Ohman MD (1990) The demographic benefits of diel vertical migration by zooplankton. Ecol Monogr 60:257-281

Olla BL, Davis MW (1990) Behavioral responses of juvenile walleye pollock Theragra chalcogramma Pallas to light, thermoclines and food: possible role in vertical distribution. J Exp Mar Biol Ecol 135:59-68

Olla BL, Studholme AL, Bejda AJ (1985) Behavior of juvenile bluefish Pomatomus saltatrix in vertical thermal gradients: influence of season, ternperature acclimation and food. Mar Ecol Prog Ser 23:165-175

Pastoureaud A (1991) Influence of starvation at low temperatures on utilization of energy reserves, appetite recovery and growth character in sea bass, Dicentrarchus labrax. Aquaculture 99:167-178

This article was presented by K. L. Heck, Jr (Senior Editorial Advisor), Dauphin Island, Alabama, USA
Paul AJ (1986) Respiration of juvenile pollock, Theragra chalcogramma (Pallas), relative to body size and temperature. J Exp Mar Biol Ecol 97:287-293

Porter SD, Tschinkel WR (1993) Fire ant thermal preferences: behavioral control of growth and metabolism. Behav Ecol Sociobiol 32:321-329

Regal PJ (1966) Thermophilic response following feeding in certain reptiles. Copeia 1966:588-590

Rudstam LG, Magnuson JJ (1985) Predicting the vertical distribution of fish populations: analysis of cisco, Coregonus artedii, and yellow perch, Perca flavescens. Can J Fish Aquat Sci 42:1178-1188

Sinclair E, Loughlin T, Pearcy W (1993) Prey selection by northern fur seals (Callorhinus ursinus) in the eastern Bering Sea. Fish Bull US 92:144-156

Sogard SM (1994) Use of suboptimal foraging habitats by fishes: consequences to growth and survival. In: Stouder DJ, Fresh KL, Feller RJ (eds) Theory and application in fish feeding ecology. Belle W Baruch Press, Columbia, SC, p 103-131

Sogard SM, Olla BL (1993) Effects of tight, thermoclines and predator presence on vertical distribution and behavioral interactions of juvenile walleye pollock. Theragra chalcogramma Pallas. J Exp Mar Biol Ecol 167:179-195

Spigarelli SA, Thommes MM, Beitinger TL (1977) The influence of body weight on heating and cooling of selected Lake Michigan fishes. Comp Biochem Physiol 56. A $51-57$

Stich HB, Lampert W (1984) Growth and reproduction of migrating and non-migrating Daphnia species under simulated food and temperature conditions of diurnal vertical migration. Oecologia 61:192-196

Stuntz WE, Magnuson JJ (1976) Daily ration, temperature selection, and activity of bluegill. In: Esch GW, McFarlane RW (eds) Thermal ecology II ERDA Symposium Series CONF-750425. Technical Information Service, Springfield, VA, p 180-184

Vondracek B, Cech JJ Jr, Buddington RK (1989) Growth, growth efficiency, and assimilation efficiency of the Tahoe sucker in cyclic and constant temperature. Environ Biol Fish 24:151-156

Ware DM (1975) Growth, metabolism and optimal swimming speed in the haddock, Melanogrammus aeglefinus. Nature 221:274-275

Wieser W (1991) Limitations of energy acquisition and energy use in small poikilotherms: evolutionary implications. Funct Ecol 5:234-240

Wildhaber ML, Crowder LB (1990) Testing a bioenergeticsbased habitat choice model: bluegill (Lepomis macrochirus) responses to food availability and temperature. Can J Fish Aquat Sci 47:1664-1671

Woiwode JG, Adelman IR (1992) Effects of starvation, oscillating temperatures, and photoperiod on the critical thermal maximum of hybrid striped $x$ white bass. J Therm Biol 17 : $271-275$

Manuscript first received: February 10, 1995

Revised version accepted: September 14, 1995 